\title{
RNA Polymerase Inhibitor
}

National Cancer Institute

\section{Source}

National Cancer Institute. RNA Polymerase Inhibitor. NCI Thesaurus. Code C25995.

Any substance that inhibits RNA polymerase, an enzyme that catalyzes the polymerization of an RNA strand from a DNA template. 